\title{
Care without Leaders: \\ The Collective Powers of Affective Leadership
}

\author{
Iain Munro and Torkild Thanem
}

The final version of this chapter is published in Leah Tomkins (ed.) (2020) Paradox and Power in Caring Leadership, pp. 199-210. Cheltenham: Edward Elgar.

Today's leadership problem is really a symptom of a profound historical transformation, one that is currently in midstream - modern organizational forms have been destroyed and adequate replacements have not yet been invented. (Hardt and Negri, 2017, p. 8)

In this chapter we articulate a concept of 'affective leadership' based on the capacity to increase our collective powers of action. Doing so, we show how leaderless movements and organizations can foster their participants' powers of action by cultivating active affects which are independent of individual leaders. Although the effectiveness of leaderless organizations and movements has already been subject to some discussion (Crevani et al., 2010; Graeber, 2013; Sutherland et al., 2014), the present chapter explains their power in terms of their ethical and affective constitution.

Indeed, it is possible to start unfolding the power of collective leadership through ongoing discussions about the ostensible virtues of individual leaders. Here, good leaders are often portrayed as possessing special social competencies such as good organizational skills, excellent skills of persuasion as well as a host of other desirable traits such as being 'caring', 'authentic' and even 'transformational'. It is typically these social skills and virtues that legitimize the position of leaders at the top of the social or corporate hierarchy and justify that they are rewarded with status and high pay. Meanwhile, the leadership literature often celebrates the charismatic leaders of social and religious movements who are driven by ideological and altruistic aims rather than personal gain. Christ, Mohammed, Gandhi, Martin Luther King, Malcolm X and Harvey Milk have all been acknowledged as archetypal great leaders with virtually superhuman abilities to change the world for the better (see e.g. Bass et al., 1987).

However, in practice, in any large organization or social movement, very few of its members will have any prolonged contact with their purported leader; for the most part the leader will have a largely symbolic role within the movement, as the embodiment of a particular set of ideas and affects. So, it must be that in good leadership something else besides the personal 
traits and abilities of the so-called leader is doing the work. Although a leader may be the perceived embodiment of certain ideas and certain affects such as intelligence, love and martial prowess, the work of leadership is not performed until these ideas and affects start circulating beyond the body of the leader. Indeed, leadership is always a collective effort in which the spread of ideas and affects plays an important role in the movement itself and in followers' perception of their leader.

Building on these elementary observations, this chapter outlines a concept of 'affective leadership' which does not rest on an individual endowed with special virtues and competencies. Once we realize the affective nature of leadership, leadership is necessarily a leaderless endeavour which involves enhancing our collective powers and capacities for action.

In order to map out the concept of affective leadership, we will revisit our previous work in this area and draw further on the writings of the $17^{\text {th }}$ century philosopher Benedict de Spinoza (Munro and Thanem, 2018). While Spinoza's 'joyful affects' bear some resemblance to some of the virtues endorsed by contemporary arguments for 'caring leadership', he teaches us that our capacity to enhance such virtuous affects is always a collective effort which exceeds the ostensible virtues of individual leaders. Through illustrative examples, we will then contrast how affective leadership is actualized within social movements by examining what kinds of virtues and affects they thrive on. Whereas affective leadership within social movements have increased their members' capacity for action, supposedly virtuous and caring business leaders have done little beyond enhancing their own wealth and social status. Finally, we argue that social movements and organizations striving for genuine change will need to 'immunize' themselves against individual leaders to stand a chance at enhancing their collective powers of action.

\section{Affective leadership}

Elsewhere we have defined affective leadership as a radically democratic practice devoted to enhancing our collective powers of action (Munro and Thanem, 2018). Drawing on the ethical and political writings of Spinoza, we have formulated a number of basic principles of this form of leadership, which may be summarized as follows:

1. Affective leadership diverges from the idea of the leader-follower relationship, which ultimately rests on the virtue of obedience.

2. Affective leadership is based on collective action without interference from purported 'ethical leaders'.

3. Affective leadership entails the cultivation of joyful affects such as love and courage, which increase our collective powers of action, and the avoidance of sad passions such as hatred and pity, which decrease them.

4. Our collective capacity for action develops from good encounters that accord with our reason and enhance our capacity to affect and be affected. In turn, our capacity to affect 
and be affected is enhanced as we experience and understand the limits of our freedom and the causes of joyful affects.

5. Thus, affective leadership involves the organization of good encounters through the cultivation of friendships that enable people to pursue their common advantage and welfare and the development of democratic relations that enable people to think what they wish and say what they think. Not to be confused with the nepotism flourishing in homosocial executive networks, we are more likely to enhance our affective capacities by crafting amicable relations with people who are different from us yet share our desire for the common good.

There are some important affinities between our notion of affective leadership and current arguments for caring leadership which more or less explicitly draw inspiration from the virtue ethics of the Ancient Greeks and the Ancient Romans (see e.g. Knights and O'Leary, 2005). Care is often associated with the ability to be kind and compassionate towards others. Spinoza defined compassion and kindness as joyful and virtuous affects that enhance our power to affect and be affected by others. He viewed compassion as a form of love where one is gladdened at someone else's fortune but saddened by their misfortune (DefAff24). However, one key difference between the two concepts is that caring leadership is historically grounded in a notion of pastoral care, which, emphasizing the patriarch's power to care for himself and his household, pacifies those who are subject to his care.

While care as such may be associated with "interdependency, mutual assistance ...[and] solidarity..." (Kittay et al., 2005, p. 465), talk of 'caring leadership' comes with managerialist and hierarchical connotations that risk entrenching the practice of care in conditions of exploitation and a gendered division of labour. As Kittay and colleagues $(2005,2006)$ have argued, the system of carework on which our society is grounded does not require 'caring leadership' but relations of solidarity and 'mutual care'.

Not only are such relations at the core of Spinoza's ethical sociality, Spinoza explains how they may be crafted and cultivated. Assuming that virtue is itself a form of power, he maintained that our collective powers of action are strengthened through social interactions which enable us to use and develop our reason, learn from each other, and foster convivial relations with others across and in spite of our differences. Whereas contemporary calls for caring leadership continue to frame care primarily as a virtue characteristic of individual leaders, Spinoza insists that the cultivation of any virtuous affect - and the good life as such - is necessarily a collective accomplishment that rests on our joint capacity to cultivate and use our collective powers. Through what he calls the "principle of common life and common advantage" (EIVP73Dem), "... everyone who is led by reason desires for others also the good he wants for himself" (EIVP73S). Let us therefore not be tricked by Spinoza's seemingly brutal equation between power and virtue. ${ }^{1}$ Recognizing that our capacity to live a good social life depends on our

\footnotetext{
${ }^{1}$ The equation between power and virtue is most explicitly articulated when he claims that "The more one strives, and is able, to seek his [sic] own advantage, that is, to preserve his [sic] being, the more he [sic] is endowed with virtue" (EIVP20; see also EIVP22C).
} 
agreement with others (EIVP38, 40), he argues that we strive to join others "in friendship" in order "to lead... [ourselves] and others by the free judgment of reason..." (EIVP70Dem).

It is worth dwelling a bit with Spinoza's notion of reason, because this too is profoundly embedded in his affective system. As Deleuze (1992) pointed out in his thesis on Spinoza, reason is our strongest affect (EIVP40-73). What Spinoza teaches us, then, is that we cannot enhance our reason and know the causes of good encounters with others without appreciating how such encounters affect us "through our bodies" as well as our minds (Munro and Thanem, 2018, p. 60). The more we seek to cut ourselves off from our affects and embodied experiences, the less we care about the consequences of making unreasonable and resentful claims that turn others into enemies rather than friends. Indeed, "it is only through our embodied experience and knowledge of our appetites that we might try and modify them so as to seek joyful encounters and avoid sad encounters" (Munro and Thanem, 2018, p. 60).

Hence, affective and caring leadership share the assumption that we must cultivate our collective powers of reason in order to understand how we may live well and work well with others. Under such conditions, the very notion that leadership is exercised by individual leaders disappears. As people engage in 'mutual caring' (Graeber, 2013) to be of 'mutual assistance' (Kittay et al., 2005) to one another, we flourish despite, rather than because of, individual leaders, and concern with the traits and virtues of individual leaders become little more than a distraction from the task of democratic self-governance. ${ }^{2}$

Affective leadership does therefore not preclude all acts of compassion or care for others. However, they only constitute joyful affects insofar as they involve a sense of 'collective responsibility' (Kittay, 2006, p. 338) that enhances everyone's capacity to act and care for each other. The challenge is to strengthen our capacity to organize good encounters between people. Developing our judgment and reason as a collective is central to this endeavour. By means of illustration, let us now discuss some of the virtues and affects that are actualized in radical social movements.

\section{Affects in leaderless social movements}

One case which illustrates the affective power of social movements is the anti-Vietnam war movement during the 1960s and 1970s in the United States. A pinnacle event in the development of this social movement was the march on the Pentagon, where up to 200,000 protestors attempted to surround and occupy the heart of the US military industrial complex. Norman Mailer's (1994) account of this march is instructive on the role of affects in the organization of the march and the attempts to disrupt and break the protest by US authorities. Mailer describes how feelings of solidarity, bravery and mutual respect drove the protestors as

\footnotetext{
2 Note that Kittay's $(2005,2006)$ feminist conception of care frames this not in terms of leadership but in.terms of mutual relations, in which the autonomy and decision making capacity of the other is fully respected.
} 
well as their indignation at the conduct of the war $^{3}$. This indignation is expressed both in protest at the actions of the state and in language itself: "the use of obscenity was indeed to be condemned - because the free use of it would wash away the nation - was America the first great power to be built on bullshit" (p. 201).

In response to these protests against the war, the bureaucracy of the police and military apparatus unleashed aggression and open violence on the protestors, as well as using techniques of humiliation to undermine the movement. Mailer describes the joy at the forward momentum of the march, the urgency in not stopping until their goal was achieved - the numerous acts of individual and collective bravery in the face of police violence, arrest and imprisonment. $\mathrm{He}$ describes the fear at witnessing the violent beating of a young woman at the hands of the police - the despair and impotence of her companions. He talks of his open admiration of his cell mate, the academic Noam Chomsky - "a slim sharp-featured man with an ascetic expression, and an air of gentle but absolute moral integrity" (p. 178). What is largely absent from this exceptional account is the direction of any leaders, where instead the role of a variety of affects takes priority - solidarity, joy, obscenity, indignation, bravery, fear, humiliation.

Mailer observes how the affective life of the organization was not only a part of the anti-war movement, but also the police state against which it fought:

For years he had been writing about the nature of totalitarianism, its need to render populations apathetic - its instrument the destruction of mood. Mood was forever being sliced, cut, stamped, ground, excised or obliterated. Mood was a scent which rose from the acts and calms of nature, and totalitarianism was a deodorant to nature. (p. 117)

The bureaucratic machine of state - the coldest of all monsters - is designed to destroy mood and in particular the dangerous affects of those individuals and groups that it considers to be a social enemy both at home and abroad:

The American corporation executive who was after all the foremost representative of man in the world today, was perfectly capable of burning unseen women and children in the Vietnamese jungles, yet felt a large displeasure and fairly final disapproval at the generous use of obscenity in literature and in public. (p. 49)

Burned bodies unseen and deodorized in the publications of the RAND Corporation, and the unending reports of military campaign victories in the US media - counterfeit sanitary measures in a system awash with bullshit. The destruction of mood was essential to prevent the mobilisation and self-organization of the people against these crimes. But the movement grew as the authorities lost their ability to deodorize their own stench, their mood intensified, and affects of outrage, indignation and solidarity moved the protestors against the machinery of the

\footnotetext{
${ }^{3}$ Note that Norman Mailer's account of the march on the Pentagon does mention some of the virtues of its leaders he takes pains to emphasize the role of its collective and affective dimensions rather than the qualities of specific individuals. Mailer himself was one of the key spokespersons for this event and a prominent voice in the antiwar movement itself.
} 
state. Perhaps one of the most surprising things about Mailer's account today is just how effective the corporate executive and state has itself become in mobilizing mood - and how similar crimes continue to be committed by the same state today in country after country - from Afghanistan to Iraq, from Libya to Syria.

A more recent account of the role of affect in the leaderless leadership of a social movement has been given by a number of participants of the Occupy movement. Harcourt (2013) reported that some participants of Occupy described it as being a "leaderless" movement whereas others called it a "leaderful" movement, where everyone could be understood as exercising leadership. The role of leadership was questioned by the Occupy movement in terms of its both its ethical limitations, to the extent that hierarchical structures could undermine democratic participation, and its strategic limitations to the extent that leaders offered a focal point and weakness that could be attacked by state authorities. David Graeber's (2013) insider account of the Occupy Wall Street movement of 2011 describes in detail the variety of organizational practices that were developed by the participants to ensure horizontal networks of democratic decision making in the movement, but also the absolute importance of practices to organize basic everyday living such as the provision of food, sanitation and living space. This was crucial in the creation of "a community without money" based on principles not just of democracy but on affects of mutual caring, solidarity and support.

The Occupy Movement created new practices for enhancing its collective affects, such as the 'human mic' where the protesters would repeat each line of any speech made to amplify the message to all those present and to enhance the collective participation and solidarity. Harcourt (2013, p.59) also observed how the human mic had "the effect of undermining leadership. It interrupts charisma. It's like live translation: the speaker can only utter five to eight words before having to shut up while the assembled masses repeat them." Techniques of massage and meditation were also used by the protestors to help relax, ease anxieties and foster feelings of solidarity (Schneider, 2011). At the same time, Graeber's account observes the difficulties in maintaining solidarity when confronted with the militarized tactics of the police who attempted to break up the movement and destroy the new social space that they had created. Thus, he bears witness to a range of intimidation tactics, including beatings, the use of pepper spray against non-violent protesters as well as micro-aggressions of degradation and humiliation.

In response to such tactics, the movement itself had required a great deal of attention to its affective dimensions. With an immense creativity which directly informed their tactics of protest, the Occupiers fostered a collective atmosphere of carnival where "love and caring was our primary weapon" (p. 258). This was not just a revolutionary challenge "to the power of money but to the power of money to determine what life was supposed to be about.... for that brief moment love had become a revolutionary act" (p. 127).

What these two examples show is that it is not individual leaders imbued with special powers or competencies that are acting as leaders, but the collective affects that are part of the social 
milieu of these movements. We will now turn to a closer examination of the ambivalent role of leadership within leaderless movements and organizations.

\section{Immunizing against leaders - enhancing collective powers of action}

The principle of a leaderless movement or organization is absolutely fundamental to the source of its power and its increase (Sutherland et al, 2014). Hardt and Negri (2017) argue that the social movements of the recent past that have fought for the increased freedoms and democratic powers of their participants are increasingly immunizing themselves against the 'leadership virus' and the hierarchical social relations that this virus brings with it. This does not mean that such movements do not have coordinators that helped facilitate public assemblies and consensus decision making, or mutual carers who helped to defuse tension and bolster solidarity, or temporary spokespersons - but to understand these roles in terms of being a leader is to misconceive their fundamentally collective and affective nature.

For example, in the Occupy movement of 2011 the lack of leaders gave the movement strength both in removing them as strategic points of weakness that could be focused upon by the police to undermine the movement, and in the stimulation of collective assemblies as decision making bodies, which helped to increase the affective commitment of the participants of the movement. The principle of leaderlessness also embodied the ethical idea of radical democracy that the movement stood for in contrast to the corrupt representative democracy against which it was directed. However, other examples can be found which equally demonstrate the ethical and tactical importance of leaderlessness in fostering the power of any movement.

One of the most famous military 'leaders' of the First World War, T.E. Lawrence, confessed that he was not really a leader and had little control of the events and the victories which others ascribed to him. Instead, he explained his role in the events as a 'mock primacy', emerging largely from the fact that many of the reports and interviews about the events were either written by him or based upon interviews with him. While it is no doubt true that he was a phenomenal organizer and a superb tactician, he left the leadership role to others (i.e., to General Allenby and Prince Faisal). Lawrence's account of the tactics of guerrilla war explained that it had far more in common with the practice of a general strike than with a traditional military campaign. The strategy of guerrilla warfare that he developed implicitly rejected the need for a leader - as the irregular forces that made up their rebellion could not be counted on to follow a leader for any length of time, his strategy focused on making it impossible for the adversary's leaders to effectively mobilize their forces. The leading was done not by him as an individual but through an assemblage of affects - through an idea of freedom, a Bedouin way of life, and the desert. Hence, one might understand Lawrence's "mock primacy" in the revolt can be understood in terms of what Skeaff (2018) calls an 'intermediary', where the role of the 'leader' is little more than a symbolic and affective idea rather than issuing from the capability or character of a particular individual. 
Skeaff (2018) elaborates the role of the intermediary through the example of another historical figure who is routinely celebrated as a charismatic leader; Moses. The figure of Moses played a peculiar role in the creation of the Jewish nation, in that he is both cast as a charismatic leader and as someone with no power of his own. Moses simply follows the order of his God and helps to organize a division of powers within a federation of autonomous tribes, which constitutes "a republic in which no single individual or group in society exercised command over the people as a whole" (Skeaff, 2018, p. 102). Notwithstanding the commanding and un-reasonable nature of the Decalogue that Moses received from God on Mount Sinai, Skeaff argues that the chief commandment which came to organize this new society was the principle whereby its members agreed to live according to the dictate that they should love their neighbour. As such, Moses was not the leader of the Israelites but the mediator of God's laws; "strictly speaking, no-one ruled" (p. 106). Again, the idea of God plays a purely symbolic and affective role - it is an empty signifier but which is attributed immense powers.

More specifically, this principle led the Israelites to establish a system of checks and balances between the tribes, including rules which mitigated against the accumulation of economic power, such as the right of a jubilee whereby debts were forgiven and properties redistributed after a period of seven years. Rather than simply expressing a moral duty, this system, and its underlying principle of neighbourly love, involved an ancient form of radical democracy which rested on the power of the community. In Skeaff's words, "loving one's neighbour as oneself is ... a necessity to take one's power to the limit through an alteration or exchange with the powers of others" (p. 117).

Instead of focusing on the magical powers of the individual charismatic leader, Skeaff observes that the institutionalization of new ways of living is always a result of judgments and actions made by the collective itself. According to Skeaff, the power of judgment plays a fundamental role in the creation and circulation of affects, which are formed and refined in common by means of mutual interaction. Skeaff explains that the power of judgment is fundamental to the constituent power of any social group and is essential to the formation of true democracy. Even when an individual acts in obedience to another they can never give up their power of judgment because this is our inalienable, constitutive power. According to Skeaff, "these judgments carry a vital normativity, a constituent power transgressing established norms and creating new norms more conducive to the common endeavor of becoming maximally free, rational, powerful..." (p. 87).

Indeed, the creation of new forms of living in common is the explicit aim of social movements such as the Civil Rights movements, LGBT movement, the Occupy movement, and Black Lives Matter. Erica Edwards explains that the glorification of individual leaders is detrimental to such movements, and is both "politically dangerous... and historically inaccurate" (quoted in Hardt and Negri, 2017, p. 30). Writing about the Black civil rights movement in the US, Edwards argues that the mythology of the charismatic leader is grounded in a stereotype of heteronormative masculinity which presents a sanitized and inaccurate historical account of the development of social movements. Frederick Harris (2015) has also argued that dependence on individual charismatic leaders such as Malcolm X or Martin Luther King was a strategic 
weakness of previous social movements. Having said that, it is inaccurate to claim that there are no leaders in Black Lives Matters (Chatelain and Asoka, 2015). However, these organizers do not act as charismatic leaders but as community organizers who help to organize protests and express the collective will of their communities from below. To prevent being dragged down by a cult of individual leaders, social movements whose aims are radically democratic have therefore sought to develop immune systems that attack signs of hierarchical authority. For instance, the recent Black Lives Matter movement which has emerged in response to police violence against blacks in the United States is self-consciously organized from the bottom-up with great skepticism of the power of individual leaders (Hardt and Negri, 2017).

\section{Conclusions}

This chapter has drawn on a number of examples of leadership in order to refine a conception of 'affective leadership', which enhances our collective capacity for action. Doing so, we have been strongly critical of the concept of leadership in general, particularly how it continues to be grounded in a mythology symptomatic of hierarchical social forms, masculine stereotypes and individual saviours. This mythology gives a largely inaccurate portrayal of the affective dimension that lead people to act in ways that enable genuine progressive change.

If anything, the individual leader plays a largely symbolic role in the organization, as the living embodiment of a particular set of ideas and affects. In good leadership something else besides the personal abilities of the purported leader is doing the work - it is always a collective effort and the spread of ideas and affects such as intelligence, love, solidarity and courage. It is these ideas and affects that are performing the work of leadership beyond the body of the leader. In order to enhance our collective powers of action, the mythology of the individual leader and leadership per se must therefore be abandoned. Instead, we must examine the social relations and collective affects which are circulating within organizations. In a world where horizontal networks of organization have found new forms of expression, it is time to reveal that the capacity of leaderless movements and organizations to increase the power of action of their participants relies on active affects that are independent of individual leaders.

Three such affects are care, reason and judgment. Although social movements are often formed as a response to painful experiences of violence and injustice, what makes them powerful is their ability to transform these experiences into joyful affects which enhance their capacity to achieve change. It is not sufficient to be dismayed and enraged by witnessing and experiencing injustice. We must learn to act together, in ways which produce the change we care about, so much so that we end up being gladdened by our joint collective fortune. Creating this new vital normativity may require courage and cheerfulness. But it also requires that we cultivate our affective powers of judgment and reason- to be able to judge and understand what is good, not just for ourselves but for all. This task cannot be off-loaded onto individuals in leadership positions but is something we all must learn through social interaction, with our bodies, by living and working in common. As our freedoms are under attack by unreasonable forces, we must learn to cultivate our power to affect progressive change by using our judgment, enhancing 
our reason, and transforming sad affects into joyful affects of care, courage and love at a collective scale.

\section{References}

Bass, B., Avolio, B, and Goodheim, L. (1987) Biography and the Assessment of Transformational Leadership at the World-Class Level, Journal of Management, 13(1):719

Chatelain, M. and Asoka, K. (2015) Women in Black Lives Matter: An Interview with Marcia Chatelain, Dissent, Summer, pp.54-61

Crevani, L., Lindgren, M., \& Packendorff, J. (2010). Leadership, not leaders: On the study of leadership as practices and interactions. Scandinavian journal of management, 26(1), 7786.

Deleuze, G. (1992 [1968]) Expressionism in Philosophy: Spinoza (trans. M. Joughin). New York: Zone.

Graeber, D. (2013) The Democracy Project: A History, A Crisis, A Movement, Penguin, London.

Harcourt, B. (2013) "Political Disobedience" in W. Mitchell (Ed) Occupy: Three Inquiries in Disobedience, University of Chicago Press, Chicago, pp.45-92

Hardt, M. and Negri, A. (2017) Assembly, Oxford University Press, Oxford.

Harris, F. (2015) The Next Civil Rights Movement, Dissent, Summer, pp.34-40

Kittay, E., Jennings B. and Wasuna, A (2005) Dependency, Difference and the Global Ethic of Longterm Care, The Journal of Political Philosophy, 13(4):443-469

Kittay, E. (2006) The Concept of Care Ethics in Biomedicine: The Case of Disability, in Rehmann-Sutter Marcus, C., Düwell, M. and Mieth, D. (eds) Bioethics in Cultural Contexts, Springer, pp. 319-339.

Mailer, N. (1994) Armies of the Night: History as a Novel/The Novel as History. New American Library, New York

Munro I. and Thanem T. (2018) The Ethics of Affective Leadership: Organizing Good Encounters Without Leaders. Business Ethics Quarterly, 28(1), 51-69.

Skeaff, C. (2018) Becoming Political: Spinoza's Vital Republicanism and the Democratic Power of Judgment, Chicago University Press, Chicago.

Spinoza, B. de (1994 [1677]) The Ethics and Other Works, edited and translated by E. Curley, Princeton University Press, Princeton, NJ.

Sutherland, N., Land, C. and Böhm, S. (2014) Anti-leaders(hip) in Social Movement Organizations: The case of autonomous grassroots groups, Organization, 21, 759-78.

\section{Acknowledgement}

Torkild's co-authorship on this chapter benefited from funding from the Swedish Research Council (2015-01523). 